\title{
Peran DPRD Dalam Tata Konstitusi dan Politik Hukum Indonesia
}

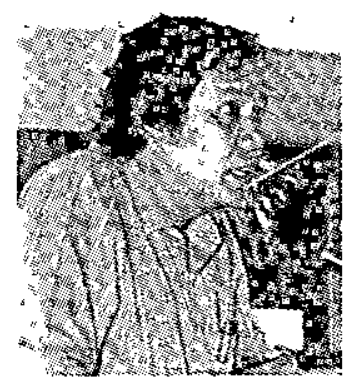

Oleh : H. Dahlon Thaib

Setelah lebih dari 20 tahun diberlakukannya UU No. 5 Tahun 1974, dalam kenyataannya, hingga saat ini DPRD masih terbatas kemampuannya, bukan saja dalam mengembangkan diri sebagai lembaga perwakilan yang mampu menjamin terselenggaranya pemerintahan dan pembangunan yang memberi manfaat sebesar-besarnya bagi peningkatan kesejahteraan di daerah, namun juga dalam melaksanakan hak-hak para anggotanya. Untuk itu, menurut $\boldsymbol{H}$. Dahlan Thaib, perlu kajian yang mendalam terhadap gagasan yang berkembang akhir-akhir ini mengenai revisi UU. No. 51974.

\section{Pendahuluan}

Sebagaimana kita ketahui, para perumus Undang-Undang Dasar 1945 dengan sengaja menyusun Undang-Undang Dasar tersebut secara "singkat" dan "supel", agar Undang-Undang Dasar itu dapat menjadi acuan yang mantap dalam masyarakat yang tumbuh dinamis. Artinya sebagai hukum dasar yang tertulis, atau sebagai konstitusi tertulis, Undang-Undang Dasar 1945 mengandung konsep-konsep dasar dan muatan materi yang bersifat pokok yang antara lain mengatur tentang sistem pemerintahan.

Penjelasan Undang-Undang Dasar 1945 menegaskan bahwa ". hukum dasar yang tertulis itu hanya memuat aturan-aturan pokok, sedang aturan-aturan yang menyelenggarakan aturan pokok itu diserahkan kepada Undang-Undang yang lebih mudah caranya membuat, merubah, dan mencabut". 1

Apabila kita mengkaji muatan materi UUD 1945, maka ada 18 ketentuan dalam UUD 1945 yang harus ditetapkan dan diatur dengan Undang-Undang, salah satu diantaranya mengenai Pemerintahan Daerah, yang diatur dalam pasal 18 UUD 1945, yang selengkapnya berbunyi :

"Pembagian Daerah Indonesia atas daerah besar dan kecil dengan bentuk susunan pemerintahannya ditetapkan

1. Penjelasan Umum UUD 1945. 
dengan. Undang-Undang dengan memandang dan mengingati dasar permusyawaratan dalam sistem Pemerintahan Negara, dan hak-hak asal usul dalam daerah-daerah yang bersifat istimewa." 2

Dari aspek politik hukum ternyata apabila dilihat dari sejarah penyelenggaraan pemerintahan di daerah diketahui bahwa pengaturan tentang pemerintahan di daerah dalam berbagai Undang-Ündang organik juga mengalami perkembangan seiring dan sesuai dengan kepentingan dan perkembangan politik negara.

Sejak proklamasi kemerdekaan sampai sekarang, ketentuan perundang-undangan yang diperintahkan oleh pasal 18 UUD 1945 tersebut telah mengalami beberapa kali pergantian yaitu sejak Undang-Undang Nomor 1 Tahun 1945, Undang-Undang Nomor 22 Tahun Tahun 1948, UndangUndang No. 1 Tahun 1957, Penetapan Presiden Nomor 6 Tahun 1959 dan Nomor 5 Tahun 1960, Undang-Undang Nomor 18 Tahun 1965 dan yang berlaku sekarang adalah Undang-Undang Nomor 5 Tahun 1974.

Perkembangan peraturan perundangundangan yang mengatur tentang pemerintahan di Daerah menunjukkan adanya pengaruh perkembangan politik dan dinamika pemerintahan di dalam masyarakat.

Tulisan ini secara kritis akan memfokuskan kajian atau studi tentang Undang-Undang No. 5 Tahun 1974 dan implikasinya terhadap peran DPRD. Dari aspek politik hukum, peran DPRD itulah hemat penulis yang cukup menarik untuk dianalisa dalam kaitannya dengan ketentuan pasal 18 UUD 1945.

Sesuai dengan amanat konstitusi tentang "........... kita harus senantiasa ingat kepada dinamika kehidupan masyarakat dan negara Indonesia," maka penulis ingin menunjukkan bahwa akhir-akhir ini dinamika masyarakat mengarah kepada isu keterbukaan dan demokratisasi dalam sistem politik Indonesia. Kedua isu tersebut telah menjadi bahan dialog yang hangat di tengahtengah masyarakat yang semakin kritis dalam menanggapai berbagai kebijakan (poitik hukum) yang digariskan pemerintah. Salah satu gema tuntutan demokratisasi adalah sekitar penyelenggaraan Pemerintahan di Daerah, terutama yang berkaitan dengan optimalisasi peran DPRD sebagai penyalur aspirasi rakyat.

Melemahnya peran DPRD di satu pihak dan menguatnya peran eksekutif di lain pihak dalam proses pengambilan keputusan yang menyangkut berbagai kepentingan merupakan salah satu alasan munculnya pro kontra mengenai revisi atas UU No. 5 Tahun 1974 sebagai Undang-Undang pelaksana terhadap ketetnuan pasal 18 UUD 1945 mengenai Pemerintaha Daerah.

\section{Landasan Konstitusional}

Sejak negara kesatuan. Republik Indonesia dibentuk melalui proklamasi dan sejak berlakunya Undang-Undang Dasar 1945 pada 18 Agustus 1945 telah beberapa káli dikeluarkan berbagai Undang-Undang tentang pemerintahan (di) daerah. Ini berarti bahwa adanya peratuan perundangundangan di bidang desentralisasi itu mempunyai arti yang strategis. Secara konstitusional hal ini merupakan perwujudan pasal 18 Undang-Undang Dasar 1945, yang memerintahkan dibaginya wilayah negara Indonesia atas daerah besar dan daerah kecil. Masing-masing dengan bentuk susunan pemerintahannya yang harus memandang dan mengingati dasar permusyaratan dalam sistem pemerintahan 
negara. $^{3}$

Oleh karena itu, menyinggung tentang peran dan keberadaan DPRD secara konsisten pijakan kita adalah UUD 1945. Tentang keberadaan DPRD penjelasan pasal 18 UUD 1945 menegaskan bahwa "Di daerah-daerah yang bersifat otonom akan diadakan Badan Penwakilan, oleh karena di daerah pun, Pemerintah akan bersendi atas dasar Permusyawaratan". Berdasarkan penegasan tersebut, maka keberadaan DPRD adalah sesuai dengan amanat UUD 1945. Masalahnya adalah sejauh mana DPRD dapat berperan dan berfungsi efektif.

Dalam konteks IImu Hukum Tata Negara, peranan Dewan Perwakilan Rakyat di daerah tidak bisa dilepaskan dari gagasan pembentukan sistem perwakilan dalam suatu penyelenggaraan pemerintahan negara yang diatarbelakangi oleh teori mengenai demokrasi. Teori ini menjelaskan bahwa peningkatan kualitas demokrasi antara lain dapat dilihat dan ditentukan oleh aktualisasi fungsi-fungsi politik yang seharusnya dijalankan oleh badan perwakilan rakyat. Melalui aktualisasi fungsi-fungsi ini penyelenggaraan pemerintahan dapat berjalan seimbang antara eksekutif sebagai penyelenggaraan pemerintahan sehari-hari dan rakyat sebagai pemegang. kedaulatan. Jadi teori ini menjelaskan bahwa anggota masyarakat mengambil bagian atau berpartisipasi di dalam proses dan penentuan kebijaksanaan. ${ }^{4}$

Sebagaimana telah kita pahami bahwa dewasa ini perwujudan dan keikut sertaan rakyat dalam proses pembuatan kebijaksanaan atau pengambilan keputusan tersebut dilakukan melalui sistem perwakilan, yaitu rakyat memilih wakil-wakilnya yang menjadi kepercayaannya untuk mewakili kepentingannya di dalam proses pembuatan kebijaksanaan tersebut. Obsesi ini ternyata menjadi suatu kenyataan, ketika para pendiri Republik ini merumuskan bentuk negara dan pemerintahan pertama kali di BPUPKI dan PPKI pada tahun 1945, secara formal menetapkan pilihan politik demokrasi sebagai satu satunya paham yang mendasari konsep ketatanegaraan Indonesia. Ketegasan terhadap pilihan demokrasi tersebut, secara eksplisit terdapat dalam pasal 1 ayat (2) UUD 1945 bahwa "kedaulatan adalah di tangan rakyat ...". Sementara para tokoh politik pada waktu itu juga menyepakati, bahwa dengan kenyataan kebhinekaan Indonesia, geografi, etnik, kebudayaan, agama dan masih ada deretan lainnya menetapkan pilihan politik pada pemancaran kekuasaan seperti yang secara tegas dicantumkan dalam pasal 18 UUD 1945 dan penjelasannya. ${ }^{5}$

Konsekuensi pasal 18 UUD 1945 tersebut, maka dalam struktur negara Republik Indonesia, suatu keharusan bagi adanya pemerintah daerah yang dijalankan secara demokratis dengan bersendi di atas dasar permusyawaratan. ${ }^{6}$

Hal ini berarti bahwa dalam lingkup daerah pun masyarakat perlu dilibatkan dalam proses pembuatan dan penentuan kebijakan pemerintah daerah. Oleh karena itu DPRD sebagai salah satu perangkat kekuasaan di daerah menjadi penting keberadaannya dalam membangun pemerintahan daerah yang demokratis. Sungguh pun demokrasi telah menjadi pilihan

\section{Prof. DR. Sri Soemantri, M. SH, Prospek Otonomi Daerah, Seminar Nasional Penyelenggaraan}

Otonomi Daerah dan Demokratisasi dl Indonesia, kerjasama jurusan HTN FH-UII Yogyakarta dengan PP. PERSAHI, tanggal 5 Februari 1994.

4. Arbi Sanit, Perwakilan Politik Indonesia, jakarta, Rajawali, 1985. hal.203.

5. Comelis Lay, 15 tahun UU no. 5 Tahun 1974 Pasang Surut Otonomi Daerah di Indonesia, Kompas, 19 Juli 1989.

6. BN. Marbun, SH., DPR Daerah Pertumbuhan Masalah dan Masa Depannya, Ghalia Indonesia, Jakarta, 1983, hal. 24. 
politik yang diyakini sebagai salah satu bentuk sistem politik yang terbaik untuk mencapai efektifitas penyelenggaraan pemerintahan negara, tetapi juga dalam kurun waktu 50 tahun bangsa Indonesia merdeka, praktek kehidupan demokrasi masih mengalami pasang surut seiring dengan arah dinamika pembangunan politik yang masih dalam proses menentukan format sistem politik ideal yang sesuai dengan demokrasi Pancasila.

Banyak pengamat berpendapat, termasuk Prof. Dr. H. Ateng Syafruddin, SH dalam kuliah tentang pemerintahan di daerah, bahwa salah satu masalah pembangunan politik di Indonesia adalah masalah yang berkaitan dengan pembagian kekuasaan antara pusat dan daerah, yaitu bagaimana menciptakan keseimbangan antara pemberian desentralisasi, sehingga dapat mendorong pembangunan dan partisipasi daerah serta menjaga stabilitas nasional. $(\mathrm{H}$. Ateng Syafruddin, Kuliah Pasca Sarjana Unpad, 1985).

Partisipasi daerah dalam menjaga stabilitas nasional secara kongkrit adalah partisipasi rakyat di daerah untuk menjaga keutuhan nasional dan keutuhan negara kesatuan. Oleh karena itu DPRD sebagai miniatur rakyat daerah dapat mencerminkan sikap politik untuk memelihara keutuhan negara kesatuan sebagaimana diamanatkan oleh konstitusi kita UUD 1945. Karena itu pula keberadaan DPRD dalam sistem negara kesatuan merupakan salah satu gema tuntutan demokratisasi dewasa ini, terlebihlebih setelah kita memasuki 50 tahun Indonesia Merdeka.

Untuk mewujudkan keberadaannya itu, DPRD mempunyai fungsi di bidang perwakilan, fungsi membuat peraturan, fungsi keuangan, fungsi pengawasan dan fungsi memilih. Masalah pelaksanaan fungsi-fungsi DPRD tersebut, salah satu faktor yang mempengaruhinya adalah apakah DPRD diberi kekuasaan yang memadai oleh UU. No.
5 Tahun 1974 sebagai pelaksanaan pasal 18 UUD 1945.

\section{Politik Hukum Terhadap Peran DPRD}

Kecenderungan yang terjadi sejak berlaku UU. No. 5 tahun 1974 (selama hampir 26 tahun terakhir) adalah bahwa kemauan politik nasional yang dituangkan dalam Undang-Undang tersebut (politik hukum) adalah kondisi ketergantungan yang sangat besar kepada pemerintah pusat. Hal yang tersebut terakhir, merupakan konsep politik hukum yang terdapat dalam UU. No. 5 Tahun 1974 yang berimplikasi terhadap peran DPRD. Untuk itu penulis mencoba menelusuri UU. No. 5 Tahun 1974 yang ada hubungannya dengan peran DPRD.

Mengenai upaya peningkatan efektivitas dan demokratisasi penyelenggaraan pemerintahan di daerah merupakan cita-cita yang sudah lama diupayakan perwujudannya. Seperangkat ketentuan tentang pemerintahan di daerah telah diatur dalam UU No. 5 Tahun 1974 tentang Pokokpokok Pemerintahan di Daerah dan peraturan pelaksanaannya. Meskipun begitu akhir-akhir ini cukup banyak dipertanyakan sejauh mana UU No. 5 Tahun 1974 tersebut telah menjamin terlaksananya mekanisme kerja yang baik dalam penyelenggaraan pemerintah daerah. Dari berbagai aspek penyelenggaraan pemerintahan di daerah, penyelenggaraan fungsi-fungsi Dewan Perwakilan Rakyat di Daerah (DPRD) telah merupakan topik yang menjadi sorotan baik dalam seminar-seminar maupun dalam tulisan-tulisan di media masa. Thema pokoknya berkisar pada anggapan tentang adanya kesenjangan antara kedudukan dan fungsi DPRD sebagaimana dirumuskan dalam UU No. 5 Tahun 1974 dengan rangkaian aktifitas yang dapat dikembangkan oleh lembaga itu dalam realitas kehidupan politik di daerah.

Pasal 13 UU No. 5 Tahun 1974 menegaskan bahwa pemerintah daerah 
terdiri dari Kepala Daerah dan Dewan Perwakilan Rakyat Daerah (DPRD). Kedua organ ini mempunyai kedudukan yang sederajad, Kepala Daerah sebagai pemimpin eksekutif sedangkan DPRD pada bidang legislatif. Tetapi dilihat dalam ketentuan pasal lain menunjukkan bahwa Kepala Daerah mempunyai kekuasaan yang lebih dibandingkan dengan kekuasaan DPRD, sebab UU ini juga menganut dualistis yaitu Kepala Daerah karena jabatannya juga merangkap sebagai Kepala Wilayah. Sebagai Kepala Wilayah, ia merupakan Wakil Pemerintah Pusat di daerah dan juga sebagai penguasa tunggal di bidang pemerintahan dalam wilayahnya, dalam arti memimpin pemerintahan,

mengkoordinasikan pembangunan dan pembina kehidupan masyarakat dalam segala bidang (pasal 80 UU No. 5 Tahun 1974).

Ketentuan lain yang melemahkan ruang gerak kewenangan DPRD adalah terlihat dalam tata cara pemilihan Kepala Daerah.

UU ini menjelaskan bahwa Kepala Daerah dicalonkan dan dipilih oleh DPRD sedikitnya tiga orang dan sebanyakbanyaknya lima orang. Selanjutnya hasil pemilihan tersebut diajukan oleh DPRD kepada Presiden melalui Menteri Dalam Negeri, sedikit-sedikitnya dua orang untuk dipilih salah satu diantaranya, dan Presiden atau Menteri Dalam Negeri tidak terikat dengan jumlah suara yang diperoleh oleh calon-calon yang diajukan (Pasal 15 ayat 1 dan 2). Implikasi dari sistem pengangkatan itu adalah pada pertanggungjawaban Kepala Daerah tidak kepada DPRD tetapi kepada Presiden melalui Menteri Dalam Negeri (Pasal 22 ayat 2). Sedangkan kepada DPRD, Kepala Daerah wajib memberikan keterangan pertanggungjawaban sekurangkurangnya sekali setahun, atau jika dipandang perlu olehnya, atau apabila diminta oleh DPRD (Pasal 22 ayat (3) UU No. 5 Tahun 1974. Tetapi dalam menanggapi pemberian keterangan pertanggungjawaban
Kepala Daerah", DPRD tidak mempunyai kewenangan yang jelas, karena tidak diatur bagaimana konsekuensinya seandainya keterangan pertanggungjawaban Kepala Daerah tidak dapat diterima oleh DPRD: Lebih lanjut dalam posisinya yang kuat: Kepala Wilayah dapat mengawasi dan mengendalikan DPRD. Hal ini secara tegas dinyatakan dalam pasal 35 ayat (1) UU No. 5 Tahun 1974 sebagai berikut : "Apabila ternyata DPRD Tingkat I melalaikan atau karena satu hal tidak dapat menjalankan fungsinya dan kewajibannya sehingga dapat merugikan daerah atau negara, setelah mendengar pertimbangan Gubernur Kepala Daerah, Menteri Dalam Negeri menentukan cara bagaimana hak, wewenang dan kewajiban DPRD itu dijalankan. Begitu juga terhadap DPRD Tingkat II sebagaimana dijelaskan dalam ayat (2) dari pasal yang sama. Sekarang yang menjadi pertanyaan adalah bagaimanakah implikasinya terhadap peranan DPRD dalam melakukan fungsifungsinya.

Menurut ketentuan UU No. 5 Tahun 1974, maka DPRD mempunyai fungsi ganda. Sebagai unsur pemerintahan daerah, DPRD adalah mitra kerja eksekutif, olef karena itu kerjasama yang serasi antara DPRD dengan Kepala Daerah seyogyanya terjamin. Dalam kedudukan sebagai wakil rakyat, anggota DPRD diberi hak-hak agar dapat melaksanakan fungsinya. Kemampuan DPRD dalam melaksanakan fungsi perwakilannya dapat dilihat dari daya persepsi para anggotanya dalam mengangkat masalah dalam masyarakat untuk dibicarakan dalam forum DPRD. Ukuran kualitas anggota DPRD terletak pada kemampuannya dalam proses mengolah tuntutan-tuntutan dalam masyarakat, serta dalam proses merumuskan dan menyalurkan masalah-masalah yang secara langsung berhubungan dengan kepentingan masyarakat ke dalam berbagai kebijaksanaan. Untuk ini diperlukan 
komunikasi yang lancar antara DPRD dengan masyarakat (rakyat) yang diwakilinya. Pasal 30 huruf d UU No. 5 Tahun 1974 menyatakan bahwa salah satu kewajiban DPRD adalah memperhatikan aspirasi dan memajukan tingkat kehidupan rakyat dengan berpegang pada program pembangunan pemerintah.

Dalam fungsi membuat peraturan, DPRD diberi kewenangan untuk membuat peraturan dearah yang dalam pelaksanaannya fungsi ini dapat digunakan melalui hak inisiatif atau hak prakarsa dan hak amandemen atau hak perubahan. Dengan dijalankannya fungsi peraturan oleh DPRD, oleh kebijakan-kebijakan pemerintah di daerah akan lebih mencerminkan kehendak rakyat di daerahnya. Tatapi dalam prakteknya fungsi peraturan ini tidak berjalan sebagaimana mestinya, sebab hak inisiatif tidak pernah dilaksanakan. Dilihat dari struktur pemerintahan di daerah yang berorientasi ke atas, sesungguhnya UU No. 5 Tahun 1974 sangat membatasi penggunaan hak prakarsa atau hak inisiatif oleh DPRD, sebab dengan diterapkannya peran ganda dalam diri Gubernur Kepala Daerah Tingkat I, Wali Kotamadya dan Bupati Kepala Daerah Tingkat II yang dalam prakteknya lebih menonjolkan perannya sebagai Kepala Wilayah, maka sebagai konsekuensinya DPRD kurang memiliki kesempatan untuk memainkan perannya sebagai legislator dalam merumuskan peraturan daerah. Pada segi lain kecilnya bobot kekuasaan Dewan dalam fungsi peraturan ini antara lain terlihat dari pengesahan Pemerintahan Pusat terhadap peraturan daerah yang sudah disepakati DPRD. Adanya pengesahan peraturan daerah oleh Pemerintah Pusat membuat anggota canggung untuk menerima dan menolak suatu rancangan peraturan daerah dan mekanisme ini juga memberi kesan bahwa Dewan bekerja secara tidak tuntas.?

Fungsi lain yang sangat penting dari DPRD adalah fungsi pengawasan, DPRD diberikan kekuasaan untuk melakukan kontrol atau pengawasan dengan mengajukan saran-saran, pendapatpendapat dan sebagainya yang perlu dipertimbangkan oleh Kepala Daerah. DPRD diberikan kekuasaan untuk memberikan penilaian terhadap kebijaksanaan dan tingkah laku pihak eksekutif dalam menjalankan pemerintahan (pasal 22 ayat (3) UU No. 5 Tahun 1974 jo Keputusan Mendagri No. 5/1975). Peranan DPRD dalam melakukan fungsi pengawasan sangat penting untuk mencegah terjadinya penyalahgunaan, penyelewengan dan kebocoran yang dilakukan oleh pihak eksekutif dalam menyelenggarakan pemerintahan di daerah. Sebenarnya dalam melaksanakan fungsi pengawasan DPRD mempunyai kesempatan yang luas sebagaimana diatur dalam sejumlah pasal dari UU No. 5 Tahun 1974 (lihat antara lain pasal-pasal 22, 29). Sungguhpun DPRD mempunyai kesempatan yang luas untuk melakukan fungsi pengawasan sebagaimana diatur dalam pasal-pasal tersebut di atas, tapi dalam prakteknya fungsi pengawasan tersebut belum berjalan secara efektif. Salah satu sebabnya karena Kepala Daerah tidak bertanggung jawab kepada DPRD.

Dalam praktek fungsi pengawasan belum berjalan efektif, sebagai misal dari kenyataan ini, adalah dilihat dari keluaran kebijakan di daerah yang lebih mencerminkan produk pemerintahan dari pada realisasi keinginan rakyat melalui badan perwakilannya....... sementara persetujuan rakyat melalui DPRD lebih untuk memenuhi tata cara politik semata. Pada tingkat-tingkat daerah, yang memerlukan persetujuan DPRD hanya proyek-proyek yang biayanya

7. Arbi sanit, Peranan Dewan Perwakilan Rakyat Daerah di Indonesia, Jumal Penelitian Sosial, No. 8

Tahun 1980, hal. 28. 
berasal dari pendapatan daerah. dan

hanya kurang dari $20 \%$ kebijaksanaan pembangunan di daerah dilaksanakan melalui persetujuan DPRD, sebagian besar lainnya, $80 \%$ sampai saat ini dilaksanakan dengan tidak melibatkan DPRD dalam penyusunan kebijaksanaan, pelaksanaan maupun pengawasan. ${ }^{8}$

Dari apa yang dikemukakan tentang peran DPRD seperti sekarang ini, maka untuk masa yang akan datang perlu dipertimbangkan adalah bagaimana caranya memberikan kesempatan kepada DPRD agar dapat berperan lebih efektif sebagai salah satu lembaga demokrasi yang diakui keberadaannya di negara yang menganut paham kedaulatan rakyat sebagaimana diamanatkan oleh UUD 1945.

\section{Alternatif Pemikiran}

Dari uraian-uraian yang telah dikemukakan di atas kita mengetahui bahwa ketidak fungsian atau kelemahan DPRD sebagian bersumber dari UU No. 5 Tahun 1974 yang tidak memberi bobot kekuasaan yang memadai kepada DPRD untuk dapat melaksanakan

fungsi-fungsinya. Bagaimanapun juga upaya peningkatan fungsi dan peranan DPRD bukanlah merupakan hal yang sederhana. la terkait dengan berbagai faktor baik yang terdapat di dalam maupun di luar DPRD itu sendiri. Dalam rangka peningkatan peran DPRD perlu diadakan peninjauan kembali UU No. 5 Tahun 1974 yang oleh banyak pihak UU tersebut dalam perwujudannya masih terdapat kelemahan dan kekurangannya, sebagaimana dikemukakan oleh mantan Wakil Gubernur Lemhannas Prof. Drs. S Pamudji, MPA. (Alm) yang berpendapat : "Undang-Undang No. 5 Tahun 1974, perlu dikaji ulang. Sebab UU tersebut sudah tidak sesuai dengan kebutuhan sekarang dan masa yang akan datang ......" s

Hal yang sama juga disampaikan oleh mantan Menteri Dalam Negeri Jenderal Rudini, juga mengemukakan bahwa UU No: 5 Tahun 1974 perlu dikaji ulang, sebab UU ini perlu disesuaikan dengan kebutuhan di masa depan, sebagai misal,"... perlu pengaturan kembali tentang pemerintah daerah sebagai pelaksanaan asas desentralisasi yang mengacu pada pasal 18 UUD 1945". ${ }^{10}$

Akhirnya dalam mendukung ke arah pemberian wewenang politik yang memadai bagi daerah, maka perlu diciptakan struktur pemerintah daerah yang lebih demokratis. Sebagai misal, peran Kepala Wilayah sebagai wakil Pemerintah Pusat dan juga sebagai penguasa tunggal perlu ditinjau kembali. Dalam Teori Hukum Tata Negara Indonesia sesungguhnya konsep penguasa tunggal tidak dikenal karena tidak sesuai dengan ajaran kedaulatan rakyat yang dianut oleh UUD 1945.

Dengan demikian konstruksi pemerintah daerah adalah Kepala Daerah dan DPRD, perlu dirubah menjadi Kepala Daerah yang dikontrol DPRD, karena secara konstitusional hal ini sesuai dengan amanat UUD 1945. Sementara DPRD yang perlu diberi kewenangan untuk memilih dan menentukan Kepala Daerah, sudah barang tentu kalau pola ini diterapkan, maka Kepala Daerah harus bertanggungjawab kepada DPRD. Struktur pemerintahan daerah yang demikian akan lebih memungkinkan DPRD untuk melaksanakan fungsi-fungsinya secara optimal dan dalam perspektif inilah esensi kehidupan berdemokrasi dalam pemerintah di daerah akan lebih bermakna. Hal lain yang perlu dikemukakan adalah bahwa kelemahan-kelemahan DPRD dalam

8.Sofian Effendi, Hambatan Struktural Pengawasan Legislatif, Prisma, LP3ES, jakarta, 1989, No. hal 15-16. 9. Berita Buana, Rabu 22 Mei 1991.

10. Berita Buana, Rabu 5 Juni 1991 
melaksanakan fungsi perwakilan selain ditentukan oleh kualitas anggota secara individu juga terkait dengan sistem pemilihan dan prosedur untuk menjadi anggota. Sistem pemilihan perwakilan berimbang yang kita gunakan tidak menyeleksi calon secara langsung, seleksi hanya berlangsung pada tingkat organisasi peserta pemilihan umum. Ikatan pada anggota DPRD dengan orsospol sangat kuat, telah melemahkan hubungan mereka dengan rakyat pemilih. Banyak diantara anggota DPRD yang kurang dikenal dan kurang akrab dengan rakyat pemilih. Jadi upaya peningkatan DPRD sebagai wakil rakyat juga berhubungan dengan penataan sistem pemilihan, dalam mana proses rekruitmen untuk menjadi anggota DPRD itu berlangsung.

\section{Penutup}

Setelah lebih 20 tahun diberlakukannya UU No. 5 Tahun 1974, kenyataan bahwa hingga dewasa ini DPRD masih terbatas kemampuannya, bukan saja dalam mengembangkan diri sebagai lembaga perwakilan yang bermakna yang mampu menjamin terselenggaranya pemerintahan dan pembangunan yang memberi manfaat sebesar-besarnya bagi peningkatan kesejahteraan di daerah, tetapi juga terbatas di dalam melaksanakan hak-hak para anggotanya.

Keadaan ini mengharuskan adanya langkah-langkah yang lebih kongkrit dalam bidang politik hukum untuk memungkinkan optimalisasi peran DPRD pada masa-masa yang akan datang. Untuk itu semua perlu kajian yang mendalam terhadap gagasan pemikiran yang berkembang akhir-akhir ini mengenai revisi UU No. 5 Tahun 1974. Yang perlu kita catat adalah kebijakan pemerintah Orde Baru dalam bidang pembangunan politik yang telah membuahkan stabilitas politik yang memadai dan semakin kokohnya persatuan dan kesatuan bangsa. Oleh karena itu kekhawatiran timbulnya disintegrasi nasional, untuk memberikan perluasan desentrasilasi pada daerah perlu dihindari.

\section{DAFTAR PUSTAKA}

Arbit Sanit, "Perwakilan Indonesia", Jakarta, Rajawali, 1985, Hal. 203.

---------, "Peranan Dewan Perwakilan Rakyat Daerah dan Indoneșia", Jurnal Penelitian Sosial, 1980, hal.28.

BN. Marbun, S.H., "DPR Daerah Pertumbuhan Masalah dan Masa Depannya", Ghalia Indonesia, Jakarta, 1983. Hal. 24.

Sri Soemantri, M.SH, Prof. Dr., "Prospek Otonomi Daerah, Seminar Nasional Penyelenggáraan Otonomi Daerah Demokratisasi di Indonesia", kerjasama Jurusan HTN FH UII Yogyakarta dengan PP PERSAHI, tanggal 5 Februari 1994. Sofian Effendi, "Hambatan Struktural Pengawasan Legislatif", Prisma, LP3ES, Jakarta, 1989, No. Hal. 15-16.

Prof. Dr. H. Ateng Syafruddin, SH. Materi Perkuliahan tentang Hukum Pemda pada Fakultas Pasca Sarjana UNPAD Bandung, 1995.

Kompas, 19 Juli 1989

Berita Buana, Rabu 22 Mei 1991

Berita Buana, Rabu 5 Juni 1991

UUD 1945

UU No. 5 Tahun 1974

广H. Dahlan Thaib , SH,MSi, adalah alumni FH UII. Gelar master diperoleh dari UGM Yogyakarta. Kini sebagai dosen FH UII sekaligus Ketua Program Magister Hukum UII. Saat ini sedang menyelesaikan Program Doktor di UNPAD Bandung. 